- $\quad$ Research in Language 2007, vol. 5

DOI: 10.2478/v10015-007-0011-5

\author{
Andrew Wilson*
}

Lancaster University

\title{
WORDS FOR WOMEN'S BOOTS \\ IN PRESENT-DAY POLISH: A QUANTITATIVE AND CONTRASTIVE ONOMASIOLOGICAL STUDY
}

\begin{abstract}
:
Footwear terminology demonstrates interesting cross-linguistic differences and is, consequently, also a problematic area for non-native speakers. In order to arrive at a more accurate picture of a subset of footwear terminology in present-day Polish, 82 native speakers were asked to name a range of six contemporary women's boot styles. No style showed a complete agreement in the preferred head noun, although a clear trend was evident for each one, with kozaki being the most commonly used overall. The possibly uniquely Polish use of a military metaphor for tall riding-style boots (oficerki) and the special subcultural case of Dr. Martens-style boots are discussed in particular. The choice of modifiers within noun phrases for boots is also examined. Some contrastive data are presented from speakers of Greek and Russian.
\end{abstract}

Keywords: Polish; onomasiology; terminology; footwear; boots; dictionaries; learner language; elicitation experiments; subcultures.

\section{Introduction}

In a previous paper, as part of a larger project on apparel-based non-verbal communication, a colleague and I employed computer-assisted content analysis to begin to examine differences in the perception of shoe styles between German, Polish and Russian students (Wilson \& Moudraia 2006). The data we used for that study consisted of a set of open-ended compositions written in English by students in each of the three countries (Germany, Poland and Russia), in other words, a corpus of L2 learner discourse. In analysing these data, it became clear that words for footwear styles were a somewhat problematic area, even for advanced learners of English. For example, some terms used by the students - such as glans - were clearly direct borrowings

* Author's address: Linguistics Department, Lancaster University, Lancaster LA 14 VT UK; e-mail: eiaaw@exchange.lancs.ac.UK. 
from the L1 and suggested confusion about which (if any) English term should be used of a particular style. Similarly, more acceptable but nevertheless outmoded English terms were sometimes employed: for instance, the Russian students repeatedly used the term top boots to refer to their knee-high boots, although this term is now considered antiquated in native-speaker English.

It is not difficult to see why language learners should have such a problem with footwear vocabulary. If we look in a typical bilingual dictionary, we can rapidly discover that footwear is often one of the less well treated areas of the vocabulary. For example, if we look for the English word boot in two pocket-sized English-Polish dictionaries, we find the following:

(1) Langenscheidt Pocket Polish Dictionary (Grzebieniowski n.d.) boot [but] $s$ but

(2) Longman podręczny stownik (Fisiak et al. 1999)

boot /bu:t/ $\mathrm{n}$ [C] 1 trzewik, but $\mathrm{z}$ cholewa: hiking boots 2 kozaczek

So, two different bilingual dictionaries, two different sets of translations.

Things become even more complicated when we then look for words to translate the related term shoe:

(3) Langenscheidt Pocket Polish Dictionary

shoe [«u] s but, trzewik; podkowa; okucie

(4) Longman podręczny stownik

shoe1 /:u:/ n [C] 1 but: a pair of shoes $D$ tennis shoes

In this case, one translation (but) is suggested by both dictionaries, but the Langenscheidt English-Polish dictionary also makes three additional suggestions.

Putting these two sets of definitions together, the situation can be summarized as follows:

- The Langenscheidt English-Polish dictionary makes no clear distinction in its Polish translations of English boot and English shoe, giving but as the only translation for boot and also as the first translation for shoe. It does offer further options for shoe, although without explanations as to what (if any) the differences are between them.

- The Longman dictionary distinguishes two numbered senses of boot. Confusingly, for the first sense, it uses a word which the Langenscheidt dictionary gives only as a translation for shoe (viz. trzewik), and it omits this from its own list of translations for shoe. It also, for the first sense, 
gives the Langenscheidt dictionary's boot word, but with a prepositional phrase modifier - but z cholewa. For the second sense, it introduces a further word for boot - kozaczek - which is completely absent from the Langenscheidt volume. Again, no explanation is given as to which of the various terms is appropriate in which context.

Clearly, this situation is unhelpful for a learner: no explanations are given for the different terms and there is substantial disagreement between two reference works from reputable dictionary publishers. There may be several reasons why these two dictionaries differ, including diachronic change in both objects (cf. Zgusta 1990) and words, since they were published some forty or so years apart; however, the diachronic development of this semantic field is not the primary focus of the present paper.

Let us glance finally at a larger, more recent dictionary - the PWN-Oxford Wielki stownik angielsko-polski (PWN-Oxford 2004) - where we are offered a larger selection of possibile translations:

(5) boot1 /but/ $\mathrm{n}$ 1. (footwear) but $\mathrm{m}$; (high) bot $\mathrm{m}$, botek $\mathrm{m}$, kozak m, kozaczek m; (laced) trzewik m ra; a pair of $E_{S}$ para butów; calf-length $E_{\mathrm{L}}$ but or botek do pół łydki; thigh $E_{\mathrm{c}}$ botek za kolano; climbing/rugby $E_{\mathcal{S}}$ buty do wspinaczki/do gry w rugby

Here, a few additional head nouns are included (kozak, bot, botek), as well as specialized terms for calf-length boots, thigh boots, climbing boots and rugby boots, and some explanation is also provided to distinguish between boot as a generic footwear term (but), laced boots (trzewiki), and high boots (botki, kozaki, kozaczki). But we may still, for instance, reasonably ask the question: can all 'high boots' be called botki, kozaki or kozacki interchangeably - i.e., are these terms true synonyms, or do native speakers use them in different proportions for different kinds of boots?

What I want to do here is to approach the issue from a synchronic onomasiological - rather than semasiological - viewpoint (cf. Quadri 1952; Baldinger 1964; Hüllen 1990; Geeraerts 2002) and to identify those words that present-day native speakers of Polish use to refer to a range of current women's boot styles. On the basis of these primary data, I then want to attempt to infer the criteria for the choice of one term over another. In this way, it will be possible to lay the foundations for a more reliable entry for boot in a bilingual English-Polish dictionary. ${ }^{1}$

\footnotetext{
${ }^{1}$ It seems that onomasiological studies of footwear terms are rather rare. The rather comprehensive bibliography of Onomasiology Online cites only two works that have focussed on shoes (Grzega 2004).
} 
Drawing on data from a large number of informants, and also some contrastive data from speakers of Russian and Greek, this paper takes a quantitative rather than a merely qualitative approach to the problem. Geeraerts (2002) and Grondelaers and Geeraerts (2003) draw attention to the contributions that a quantitative onomasiology can make in shifting the focus of research to the structuring of conceptual as well as lexical cognition. Their own work has focussed primarily on the quantitative analysis of data from text corpora; here, the quantitative approach is extended to elicited informant data.

\section{Materials and Method}

This was an elicitation experiment with (mostly young) native speakers. The informants were 82 native speakers of Polish with a mean age of 21.66 years $(\mathrm{SD}=8.61)$. Fifty informants were female and 32 were male. Some of the participants were students on a joint MA course run by Lancaster University, UK, and Łódź University, Poland. The majority, however, were acquaintances and students of members of that course. ${ }^{2}$

As part of a somewhat larger questionnaire, the informants saw photographs of six different modern women's boot styles and were asked to write down what they would call each style. They were asked to imagine that they were asking a relative to get that pair from their shoe closet by completing a Polish translation of the sentence "Please get me my ...".

The styles presented were as follows:

1) an ankle boot with a squared toe and a block heel of approx. $4 \mathrm{~cm}$ in height. The boots have a wide elastic insert extending down the outside of the shaft (like a Chelsea boot) and a zipper fastening along the inner side.

2) a pair of knee-high pull-on boots in a leather-like stretch material with a high chisel heel (approx. $6 \mathrm{~cm}$ ).

3) a pair of classic Dr. Martens boots, ankle high, with eight rows of eyelets.

4) a pair of "chunky" knee-length boots with a squared toe and a block heel of approx. 4-5 cm in height. The boots have a broad strap and buckle decoration at the ankle and a zippered fastening along the inner side of the shaft.

5) a pair of ankle-length boots whose tops fall just on the ankle bone. These boots are lower on the ankle than styles (1) and (3). The boots have a long narrow toe and a stiletto heel of approx. $5 \mathrm{~cm}$ in height.

\footnotetext{
${ }^{2}$ I am very grateful to Aneta Smolińska, Sylwia Winiarek, Iwona Wiśniewska, and Natalia Zimnowodzka for their help in the collection of these data.
} 
6) a pair of riding-style fashion boots. These boots are knee-length with a very low, wide heel and a rounded, very slightly pointed toe. There is a zipper along the inner side of the shaft and a narrow (ca. $1 \mathrm{~cm}$ ) strap decoration around the ankle. The pair in the photograph are highly polished.

From the results of this naming experiment, I first tabulated the frequencies of the head nouns used for each style and then examined any modifying phrases that were used in relation to them.

\section{Results}

\subsection{Head Nouns}

Tables 1 to 6 give the frequency of the terms chosen by the respondents for each boot style. Blank responses are not included in these tables. Where a second figure is given in brackets, this means that one or more respondents gave two names to the same style, which were not hyphenated as compounds.

Table 1. Elastic-sided ankle boots

\begin{tabular}{|l|c|}
\hline kozaki & 46 \\
\hline kozaczki & 12 \\
\hline botki & 12 \\
\hline buty & 4 \\
\hline trzewiki & 3 \\
\hline półkozaki & 3 \\
\hline półbuty & 1 \\
\hline
\end{tabular}

Table 2. Knee-length stretch boots

\begin{tabular}{|l|c|}
\hline kozaki & 72 \\
\hline kozaczki & 6 \\
\hline buty & 3 \\
\hline botki & 1 \\
\hline
\end{tabular}


Table 3. Dr. Martens boots

\begin{tabular}{|l|c|}
\hline trapery & 38 \\
\hline martensy & 17 \\
\hline glany & 13 \\
\hline trzewiki & 3 \\
\hline glany-trapery & 2 \\
\hline glany-martensy & 2 \\
\hline trapery-martensy & 1 \\
\hline traperki & 1 \\
\hline marteny & 1 \\
\hline półbuty & 1 \\
\hline bałagony & 1 \\
\hline przeszłościowe & 1 \\
\hline
\end{tabular}

Table 4. Chunky knee-length boots

\begin{tabular}{|l|c|}
\hline kozaki & 69 \\
\hline wysokie obcasy & 4 \\
\hline kozaczki & 3 \\
\hline buty & 3 \\
\hline oficerki & $1(1)$ \\
\hline mazurki & 1 \\
\hline
\end{tabular}

Table 5. Stiletto-heeled ankle boots

\begin{tabular}{|l|c|}
\hline kozaki & 25 \\
\hline szpilki & 18 \\
\hline botki & 15 \\
\hline kozaczki & 9 \\
\hline półbuty & 4 \\
\hline półkozaki & $3(1)$ \\
\hline trzewiki & 3 \\
\hline buty & 2 \\
\hline sindbady & 1 \\
\hline
\end{tabular}


Table 6. Riding-style boots

\begin{tabular}{|l|c|}
\hline kozaki & $32(1)$ \\
\hline oficerki & 30 \\
\hline buty & 14 \\
\hline kozaczki & 3 \\
\hline junaki & 1 \\
\hline lateks & 1 \\
\hline
\end{tabular}

It will be seen from these tables that kozaki - a term not mentioned by either of the pocket dictionaries as a translation for boot - is the preferred head noun used to describe almost all kinds of boots, regardless of leg height or other characteristics. ${ }^{3}$ The only exception to this trend was the Dr. Martens boot, for which other terms were used and for which kozaki was not used at all. I shall return to the Dr. Martens boot later.

The word kozaczki, which is one of the suggested terms in the Longman dictionary, seems, in reality, to be used very rarely. Only a small minority of the informants used it, although, as with kozaki, it was used of all boot styles except for the Dr. Martens boot. However, it was used significantly more often for ankle-length boots (21/164) than for knee-length boots (12/246). As measured by Fisher's exact test, the odds ratio is 2.86, two-tailed $\mathrm{p}=0.005$, 95\% ci 1.30-6.57. Stanisławski's (1982b) larger Polish dictionary translates kozaczki as "fur topped half length boots", which is clearly too narrow a definition in view of its use for the styles presented in this experiment.

Botki (another word not mentioned in either of the two pocket dictionaries) was the most common alternative to kozaki for ankle-length boots, again excluding the Dr. Martens boots, for which it was not used at all. It was used with the same frequency as kozaczki for the elastic-sided boot and was preferred to kozaczki by a ratio of almost $2: 1$ in relation to the stiletto ankle boot. It was used only once in relation to a knee-length boot.

Trzewiki (which is mentioned by the Longman dictionary as a translation for boot and by the Langenscheidt dictionary as a translation for shoe) is even rarer than kozaczki. Out of the 246 responses on the three ankle-length styles, it was used a total of just nine times. It was used in relation to all three styles of ankle-length boots (including the Dr. Martens boots), but not for any of the knee-length styles.

\footnotetext{
${ }^{3}$ Plural forms will be used throughout, as these were the forms most commonly used by the respondents.
} 
Of the knee-length boots, the riding-style boot provided the most competition for the term kozaki. Here, the term oficerki was used almost as frequently as kozaki. (It was also used twice for the chunkier knee-length boots, but not at all for the knee-length stretch boots.) Oficerki does not occur in either of the pocket-sized bilingual dictionaries. It does appear in Stanisławski (1982b) with the translation 'knee-boots' but it does not appear under the headword boot in the corresponding English-Polish volume (Stanisławski 1982a). On the basis of these data, Stanisławski's definition appears to be overly broad: oficerki seems to be used almost exclusively for flat heeled, riding-style boots, and very rarely indeed for a knee-length fashion boot with a higher heel. The military term is interesting, as in many other languages - including both English and German - this style would most commonly be referred to as riding boots (Ger. Reitstiefel). There may be two reasons for the military term in Polish. First, the association between high boots and military officers may be more strongly engrained in the Polish psyche - in other words, this may be a cultural difference in prototypical associations. Some further contrastive work would be required to substantiate this claim. This illustrates the continuing importance of Meringer's (1909) call for cultural studies - "from the trivial to the sublime" (Hüllen 1990: 141) - alongside linguistic studies. It also highlights the value of Fillmore's (1977) scene-and-frame semantics as an approach to word meaning, in that it takes account of prototypical scenes of usage and not just the physical attributes of an object. Indeed, it is possible to see Fillmore's scene-based approach to the meaning of Wörter as a development of Meringer's cultural investigations of Sachen. The other possible explanation for the popularity of the term may be connected with word length and the principle of least effort (Zipf 1949; Ferrer-i-Cancho \& Sole 2003): oficerki is a single foursyllable word, whereas the alternative terms for riding boots in Polish are phrases of five syllables or more - for instance, buty z jakonny or buty dla zakonnicy.

Apart from the riding-style boot, the stiletto ankle boot showed the smallest frequency difference between the most and next most commonly chosen term. However, after kozaki, the preferred term was not a basic 'boot' word - although botki came a near third - but rather a reference to the heel shape and height, szpilki. It is not clear on the basis of these data alone why this should be the case. However, two possibilities suggest themselves. The first possibility is that the boot in question infringed on a fuzzy boundary between the respondents' 'boot' category and 'shoe' category. Certainly, it is perceptibly somewhat lower on the ankle than the other ankle-length boot, the elastic-sided boot, and the style also demonstrated a high level of disagreement in the Russian and Greek versions of this questionnaire (see Section 3.3 below). 
However, if uncertainty between 'boot' and 'shoe' were the root cause, we would expect the prototypical terms for 'shoe' and 'low shoe' (buty and pótbuty) to occur more frequently as competitor terms in relation to this boot. In practice, however, they were barely more frequent than for the elastic-sided boot, which did not have a non-basic footwear term in the list of head nouns. The other, perhaps more likely, possibility, therefore, is that stiletto heels are more salient categorizing features than leg height. This would appear, however, to be a language- or culture-specific response, since the Russian and Greek respondents did not use any heel-related head nouns. Further research may be required to replicate or explain this phenomenon.

The generic term buty, which is the only term for boot given by the Langenscheidt dictionary, also occurred several times, but always with some form of specifying modifier. Modifiers are discussed below in Section 3.4.

A few other, rarer, terms are worth noting very briefly. Pótkozaki is a compound of kozaki; it was used rather rarely and only in relation to ankle-length boots. A similar compound is pótbuty. This is normally used for ordinary (low) shoes, but appeared in these responses a small number of times in relation to ankle boots: it was used once each for the elastic-sided boot and the Dr. Martens boot and four times in relation to the stiletto boot. Mazurki was used by one respondent in relation to the chunky knee-length boot; however, the term was not used of either of the other knee-length styles. The term junaki (lit. "brave") appeared once in relation to the riding-style boot, apparently another example of a military metaphor (like oficerki above). The word lateks also appeared in relation to this style; the person who used this term appears to be responding to the sheen that is evident on the boots in the photograph.

\subsection{Dr. Martens Boots}

Dr. Martens boots are a special case where a particular brand of footwear has attained the status of a cultural symbol (cf. Günther et al. 1995: 201-202; Roach 2003). The special status of the Dr. Martens boot is reflected here in the fact that the basic boot terms discussed in the previous section were not the preferred terms used by the respondents for these boots. Indeed, only four out of the twelve expressions used for this style were generic footwear terms and the most frequent of these was used only three times. Instead, brand-related terms were used more often. The Dr. Martens brand was widely identified, being used by 18 respondents as noun on its own (martensy, marteny) and by another four in compounds (glany-martensy, trapery-martensy). However, the Dr. Martens brand was not the most frequent name given to 
this style. That position is reserved for the word trapery, used by 38 respondents on its own and by three more in compounds (glany-trapery, trapery-martensy). It also appears, used by one respondent, in a different form - traperki. The term trapper boots does exist in English, as an internet search will reveal; however, it is by no means as culturally salient as the Dr. Martens brand, and so this term appears to reflect a cultural difference between Polish and English. The other commonly used term on the part of the Polish respondents was glany. This is also a highly culture-specific term and a Polish colleague - a linguistics specialist with fluent English - was unable to suggest a straightforward translation for it. What emerged from discussion, however, was a youth subculture (Hebidge 1979) whose distinctive apparel involves this kind of heavy laced ankle boot along with a lot of black leather, metal, and so on. It seems, then, that the Dr. Martens boot has a firm place in Polish subculture, but this subculture may differ from superficially similar ones in the UK or elsewhere, since it seems to draw on different, culture-specific lexical items. Again, this is a case where the cultural dimension of Meringer's (1909) Wörter-und-Sachen approach is required for further insights. ${ }^{4}$

\subsection{Contrastive Data}

In terms of the head nouns chosen, it is interesting to compare the results from the 82 Polish speakers with samples of native speakers of Russian $(\mathrm{N}=29)$ and Greek $(\mathrm{N}=36)$. These groups undertook the same task as the Polish respondents, except that the riding-style boot was not included in the Russian questionnaire, which was the first to be administered.

In Table 7, a version of the onomasiological cue validity (Grondelaers \& Geeraerts 2003) is calculated for each style in relation to the leading head noun used for that style. This is a measure of how readily an item or feature set is named by a given lexical item. In relation to a corpus of texts (e.g. product catalogues), Grondelaers and Geeraerts (2003: 75) define the measure as follows: "Onomasiological cue validity [...] can be measured by computing the ratio between the number of times that a lexical item is chosen as a name for a particular (set of) referent(s), and the total corpus frequency of that (set of) referent(s).',

In this work, using respondent data, the onomasiological cue validity was calculated instead as a ratio between the most preferred term for a particular style and the total number of responses for that style. Thus, if all subjects

${ }^{4}$ Cf. Polhemus (1994) for coverage of a number of (mostly British/American) youth subcultures and their distinctive apparel choices. 
use the same word for the same object, it has an onomasiological cue validity of 1 , and if all subjects use different words, the onomasiological cue validity will tend towards (though never actually reach) zero. Where gaps were left, the total number of responses equals the actual number of responses, not the fixed number of participants.

Looking at the figures presented, it will be seen that the highest agreement is reached on the two knee-length high-heeled styles. These show strong agreement in all three languages, though agreement in Polish is slightly lower in both cases than in Russian or Greek. In contrast, as alluded to above, the stiletto ankle boot has the lowest agreement, reaching its maximum in Greek at just 0.50 and falling to 0.30 in Polish. The other ankle boot, the elastic-sided boot, did not elicit much more agreement, except in Greek, where it attained a ratio of 0.72 . The remaining two styles - the Dr. Martens boot and the riding-style boot - showed quite a high degree of cross-linguistic difference. The Russian speakers showed very high agreement in providing a head noun for the Dr. Martens boot - which, interestingly, was not a brand- or subculture-related word - but the Greek and Polish respondents showed much less agreement on this style. With the riding-style boot, which the Russian respondents did not see, the Greek speakers agreed strongly on an appropriate term, but the Polish speakers were much more divided, as discussed above.

These figures suggest that knee-length, higher-heeled styles are readily named in all three languages, but that ankle-length styles result in much more variation amongst respondents. As we have seen with the riding-style boots and Dr. Martens boots, cultural aspects can also affect the naming of certain styles.

Table 7. Onomasiological cue validity for styles in relation to preferred head nouns in Russian, Greek and Polish

\begin{tabular}{|l|c|c|c|}
\hline \multicolumn{1}{|c|}{ Boots } & Russian & Greek & Polish \\
\hline Stretch knee boots & 0.90 & 1.00 & 0.88 \\
\hline Chunky knee boots & 0.96 & 0.97 & 0.84 \\
\hline Riding-style knee boots & - & 0.97 & 0.41 \\
\hline Elastic-sided ankle boots & 0.57 & 0.72 & 0.57 \\
\hline Stiletto ankle boots & 0.48 & 0.50 & 0.30 \\
\hline Dr. Martens boots & 1.00 & 0.39 & 0.52 \\
\hline
\end{tabular}




\subsection{Modifiers}

The head nouns used in responses to the stimuli were frequently modified by adjectives or prepositional phrases. These enable the same basic head noun to be used for quite different styles and to form the basis of analytic, multi-word terms in place of using distinct lexical items.

The most frequent and important modifiers were modifiers of dimension, indicating the height of the boot leg. For the knee-length styles, two adjectives were used - wysokie and dtugie - with wysokie being somewhat preferred. In the case of the stretch boot, 33 expressions were modified by a dimension adjective: in the case of the chunky boot, 18 were so modified, but with the riding-style boot only ten. For the ankle-length styles, the two adjectives used were niskie and krótkie, with krótkie being the preferred term. In the case of the elastic-sided boot, 26 terms carried an adjective of dimension and in the case of the stiletto boot 13. No dimension adjective was used in relation to the Dr. Martens boot. In a smaller number of cases, a prepositional phrase postmodifier of dimension was used in place of an adjective - for example, $z$ dtuga cholewka. Such phrases were used only three times of the stretch boot, twice of the elastic-sided boot, and once each of the chunky boot, the riding-style boot, and the stiletto boot.

After dimension, heel height or shape was the next most commonly encountered kind of modifier. It was especially common in relation to the stiletto boot. As already noted, the second most common head noun here related to the heel. However, a further 42 of the remaining terms were also postmodified with prepositional phrases relating to the stiletto heel, for example na szpilkach, w szpic. Other boot styles also occasionally had a heel postmodifier, such as $w$ czubek, na wysokim obcasie, na plaskim obcasie and so on. Heel modifiers were used 19 times in relation to the stretch boots, eight times in relation to the elastic-sided boots, 15 times in relation to the chunky knee-length boots, five times in relation to the riding-style boots, and once in relation to the Dr. Martens boots.

In the case of the chunky knee-length boot, the strap and buckle around the ankle also proved to be perceptually salient, in so far as it was encoded linguistically in the responses: thirteen of the responses to this style had prepositional phrase postmodifiers such as $z$ klamra $_{0} z$ klamerka, or ze sprzaczka.

With the riding-style boot, the most common non-dimensional modifier was meskie, which occurred 14 times. Since the respondents had been told explicitly that these were all women's shoes, this was a little surprising and it might possibly suggest that some participants may not have fully absorbed the instructions. Next most common was the phrase buty wojskowe (7 times), 
which continues the military metaphor introduced by the term oficerki. Modifiers related to horse riding (do jazdy konnej; ale konnicy) occurred only four times.

Other occasional modifiers encountered across the various styles denoted seasons (e.g. zimowe), the gender of the wearer (e.g. damskie), and the material (e.g. lakierki). These were all used rather rarely.

As well as having a distinct pattern of head nouns, the Dr. Martens boots also had the lowest number of modifiers. There were only three occurrences of modifiers here: one of gender (meskie again), one of heel height, and one indicating absence of metal toecaps, which are actually not visible in the photograph (glany bez metalowych nosków).

\section{Conclusions}

In this paper, I have examined the preferred Polish terms for a range of women's boot styles, based on the responses of 82 native speakers.

The word most commonly used for any kind of boot, with just one exception, is kozaki. This prototypically refers to any knee-length style, but is also used of ankle-length styles. Ankle-length boots may also be referred to as kozaczki or botki, although these terms are much less common. The word trzewiki appears to be largely obsolete, at least in regard to these referents.

Two special cases are riding boots (or boots which look like them) and Dr. Martens boots. In the case of riding boots, the term oficerki is a common alternative to kozaki. In the case of the Dr. Martens boots, the special terms trapery, martensy, and glany are preferred.

The lower the leg height of a boot style, the more confusing it seems to become for respondents in terms of finding an appropriate name. There is also some evidence to suggest that stiletto heels may be more perceptually salient than leg height when choosing a term: however, since there were no control styles for these features (the stiletto boot was also the boot with the lowest leg height), this would require further investigation.

Returning, then, to the dictionary definitions examined at the outset, we might perhaps suggest the following as a more reliable entry for boot in a pocket-sized bilingual English-Polish dictionary:

boot [bu:t] n kozak: ankleE: also (rarer) kozaczek, botek; ridingE: also oficerek, but oficerski; $\operatorname{Dr}$ MartensE: traper

In a larger dictionary, more information could be given in the definition about prototypical modifiers and relative frequencies of different terms. 


\section{References}

B a ldinger, K. 1964. "Sémasiologie et onomasiologie". Revue de linguistique romane 28, 249-272.

Behrans, L. and D. Zaefferer (eds). 2002. The Lexicon in Focus: Competition and Convergence in Current Lexicology. Frankfurt/Main: Peter Lang.

Cuyckens, H., R. Dirvén and J. Taylor (eds). 2003. Cognitive Approaches to Lexical Semantics. Berlin: Mouton de Gruyter.

Ferrer-i-Cancho, R. and R. S ole 2003. "Least effort and the origins of scaling in human language', Proceedings of the National Academy of Sciences 100, 788-791.

Fi 11 m ore, C. 1977. “Scenes-and-frames semantics'. In: Z a mpolli A. (ed.), 55-81.

Fisiak, J., A. Adamska-Sałaciak, M. Idzikowski and M. Jankowski 1999. Longman Podręczny Stownik. Angielsko-Polski. Polsko-Angielski. Harlow: Longman.

Geeraerts, D. 2002. "The theoretical and descriptive development of lexical semantics". In: B ehrens L. and D. Z a efferer (eds), 23-42.

Grondelaers, S. and D. Geeraerts. 2003. "Towards a pragmatic model of cognitive onomasiology". In: Cu y ckens H., R. D i rvén and J. T a ylor (eds), 67-92.

Grze bi en i ow ski, T. [n.d.] Langenscheidt Pocket Polish Dictionary. English-Polish. PolishEnglish. New York: Langenscheidt.

Grzega, J. 2004. Bibliography of Onomasiological Works (Last Updated: 1 September 2004). Retrieved December 1, 2004, from http://www1.ku-eichstaett.de/SLF/EngluVglSW/OnOn7.pdf

Günther, I., D. Janning, P. Langer and P. Oberheiden. 1995. "Ergebnis der Recherche zum Thema: 'Schuhe als Ausdruck der Persönlichkeit"'. Textilarbeit + Unterricht 4, 196-202.

He bidge, D. 1979. Subculture: The Meaning of Style. New York: Methuen.

Hülle n, W. 1990. "Rudolf Hallig and Walther von Wartburg's Begriffssystem and its non/acceptance in German linguistics". In: S chmitter, P. (ed.) 129-168.

Mer i n g r, R. 1909. "Wörter und Sachen”. Germanisch-Romanische Monatsschrift 1, 593-598.

Polhemus, T. 1994. Street Style: From Sidewalk to Catwalk. London: Thames \& Hudson.

Polo mé, E. (ed.). 1990. Research Guide on Language Change. Berlin: Mouton de Gruyter.

PWN-Oxford. 2004. Wielki stownik angielsko-polski. Warszawa: Wydawnictwo Naukowe PWN.

$\mathrm{Qu}$ a d ri, B. 1952. Aufgaben und Methoden der onomasiologischen Forschung: eine entwicklungsgeschichtliche Darstellung. Bern: Francke.

Ro a ch, M. 2003. Dr. Martens: The Story of an Icon. London: Collins \& Brown.

S chmitter, P. (ed.). 1990. Essays Towards a History of Semantics. Münster: Nodus.

$\mathrm{St}$ a $\mathrm{n}$ i sł a w sk i, J. 1982a. Wielki stownik angielsko-polski. Warszawa: Państwowe Wydawnictwo "Wiedza Powszechna".

St a n i $ł$ a w s ki, J. 1982b. Wielki stownik polsko-angielski. Warszawa: Państwowe Wydawnictwo "Wiedza Powszechna".

Wilson, A. and O. Moudraia. 2006. "Quantitative or qualitative content analysis? Experiences from a cross-cultural comparison of female students' attitudes to shoe fashions in Germany, Poland and Russia', In: Wils o n A., P. R a y s o n and D. A r c he r (eds).

Wils on, A., P. Rays on and D. Archer (eds). 2006. Corpus Linguistics around the World. Amsterdam: Rodopi.

Zam polli, A. (ed.). 1977. Linguistics Structures Processing. Amsterdam: North Holland.

Zg u s t a, L. 1990. "Onomasiological change: Sachen-change reflected by Wörter". In: P o l o mé, E. $389-398$.

Zi pf, G. 1949. Human Behavior and the Principle of Least Effort. Cambridge, MA: Addison Wesley. 